\title{
Early Late Pliocene Biochronology and Surface Water Temperature Variations in the Mediterranean
}

\author{
W.J. ZACHARIASSE ${ }^{1}$, J.D.A. ZIJDERVELD ${ }^{2}$, C.G. LANGEREIS ${ }^{2}$, F.J. HILGEN ${ }^{1}$ and P.J.J.M. \\ VERHALLEN ${ }^{1}$ \\ ${ }^{1}$ Institute of Earth Sclences, University of Utrecht, Budapestlaan 4, 3584 CD Utrecht (The Netherlands) \\ ${ }^{2}$ Paleomagnetic Laboratory, Fort Hoofdd ljk, Budapestlaan 17, 3584 CD Utrecht (The Netherlands)
}

(Received May 3, 1988, revised and accepted December 2, 1988)

\begin{abstract}
Zacharıasse, W.J , Zijderveld, J.D A., Langereıs, C.G., Hılgen, F J and Verhallen, P.J J M., 1989. Early Late Plıocene biochronology and surface water temperature variations in the Mediterranean Mar Micropaleontol , 14. 339-355

A high-resolution magnetobiostratigraphy is presented for the early Late Plocene in Sicily Paleomagnetic measurements on samples from 100 stratıgraphic levels provide an unprecedented high-quality polarity sequence which extends from the upper reversed Gilbert to the upper normal Gauss subchron. The resultant chronology for the early Late Pliocene provides ages for the following principal Mediterranean bioevents: (1) FOD Globorotalia crassaformis at $3.40 \mathrm{Ma},(2)$ prolonged absence of Globorotalıa punctıculata between 3.38 and $316 \mathrm{Ma}$, (3) LOD Uvigerina rutıla at $316 \mathrm{Ma}$, (4) LOD Sphaeroidinellopsis seminulina at $3.07 \mathrm{Ma}$, (5) LOD Globoquadrina altıspira at $304 \mathrm{Ma}$ and (6) LOD Cibıcıdes italtcus at $2.96 \mathrm{Ma}$.

Summer and winter surface water temperature estimates for the period 350 to $292 \mathrm{Ma}$ are based on the abundances of Globigerinoides sacculifer and Globorotalia puncticulata in 111 samples with an average resolution of some 5000 years

Short-term variations in temperature of the surface water and in colour and carbonate content of the sediment are primarily controlled by the equinoxal precession A higher seasonality during deposition of the grey-coloured, carbonate-poor facies suggests that at that time the summer solstice occurred near perihelion, whereas an inverse alignment occurred at the time of deposition of white-coloured, carbonate-rich layers This phase-relationship between the precession cycle and grey-coloured layers is also valid for the sapropels which began to intercalate in the grey-coloured layers at $294 \mathrm{Ma}$

Long-term changes in surface water temperatures include a warming between 338 and $318 \mathrm{Ma}$ followed by a cooling from 318 to $303 \mathrm{Ma}$. The warming of Mediterranean surface waters at $338 \mathrm{Ma}$ is believed to be associated with the final closure of the Isthmus of Panama. Consequent strengthening of the Gulf Stream injected larger volumes of warm surface water into the North Atlantic Drift and eastern boundary current and this caused surface water temperatures in the mid to high-latitude northeast Atlantic and Mediterranean to rise. The subsequent climatic coolıng at $318 \mathrm{Ma}$ is linked to a first stage of Northern Hemisphere continental ice growth.
\end{abstract}

\section{Introduction}

Despite the long tradition in Pliocene stratigraphy in the Mediterranean there is still surprisingly little paleomagnetic control. Good paleomagnetic records are presently available for the Early Pliocene (Zijderveld et al., 1986; Hil- gen and Langereis, 1988) and the Late Pliocene to earliest Pleistocene (Tauxe et al., 1983) and provide accurate age-estimates for the Miocene/Pliocene and Pliocene/Pleistocene boundaries. The Miocene/Pliocene boundary is anchored slightly below the base of the Thvera subchron with an age of $4.86 \mathrm{Ma}$ (Hilgen and 
Langereıs, 1988), whereas the Pliocene/Pleistocene boundary lies slightly above the Olduval subchron at approximately $1.6 \mathrm{Ma}$ (Tauxe et al , 1983) Good paleomagnetic control on the early Late Pliocene, however, is still lacking and current biochronologies for this time-span are based on transferring ages of extra-Mediterranean broevents to Mediterranean equivalents (Rio et al , 1984) or on the employment of periodicities of sedimentary cycles (Hilgen, 1987)

The early Late Pliocene is the time when the climate system passed an important threshold (e.g. Shackleton and Opdyke, 1977; Keigwin, 1982a, 1987, Suc, 1984; Ruddıman et al., 1987a ) but many more well-dated paleoenvironmental records are necessary to unravel the detalls of this climatic change.

In this paper we introduce a high-resolution magnetostratıgraphy for the early Late $\mathrm{Pl}_{1}$ ocene in Sicily, which furnishes a new and detalled biochronology for this time-span in the Mediterranean. Furthermore, the abundance record of three planktonic foraminiferal species affords a well-dated record of early Late $\mathrm{Pl}_{1}$ ocene surface water temperature variations in the Mediterranean

\section{Stratigraphic data}

The results presented here are based on a combined paleomagnetic and micropaleontological sampling campaign on the early Late Pliocene composite section of Punta Grande and Punta Piccola in Sicily (Fig. 1) The marly lithology of this section (Fig 2) is strongly defined by astronomically controlled variations in carbonate content (Hilgen, 1987) Grey to white colour varıations characterize small-scale cycles in which the grey interbeds are relatively poor in carbonate Larger scale cycles are distınguishable by the occasional occurrence of prominently indurated carbonate-rich intervals. Sapropelitic interbeds in the higher part of the section correspond to the grey coloured part of the small-scale cycles. The distinct rhythmic layering of the sediment is extremely helpful in accurately tracing taults which otherwise might upset the stratıgraphic continuity

The stratıgraphic position of planktonic foraminiferal bioevents (Fig. 2) is based on a qualitative analysis of fractions coarser than 125 micron from 145 samples. In terms of the biostratigraphy of Spaak (1983) the composite section ranges from the Globorotalia punctıculata Zone (interval 4 ) into the Globorotalla crassaformis Zone (interval 6). In applying the MPL-zonal scheme of Cita (1975) the section extends from MPL 4 into MPL 5 (Fig 2)

\section{Magnetostratigraphy}

Paleomagnetic samples were taken at 77 levels in the Punta Piccola section and at 20 levels in the Punta Grande section with an average sampling interval of $50 \mathrm{~cm}$ (Fig. 2). At each level we drilled two cores of $25 \mathrm{~mm}$ diameter. Special care was taken to remove the weathered surface and to drill in freshly coloured (blue) sediments. Inter-level distances were calculated according to Langereıs and Meulenkamp (1979)

The natural remanent magnetization (NRM) was measured on a 2 G Enterprises cryogenic magnetometer Total NRM intensities of the Punta Grande section, especially in the upper part, are rather low, between 0.02 and 020 $\mathrm{mA} / \mathrm{m}$, but well above the sensitivity of the magnetometer $(0.002 \mathrm{~mA} / \mathrm{m})$ Total NRM intensities of the Punta Piccola section are high, most of them between 1.0 and $20.0 \mathrm{~mA} / \mathrm{m}$. Total NRM directions show consistent groups of normal and reversed polarity, even before demagnetization procedures have removed any viscous or secondary component.

To determine both the characteristic remanent magnetization (ChRM) and the properties of the carrier of this remanence from its decay curve (Z1jderveld, 1975), generally two specimens per sampling level were demagnetızed progressively by using stepwise thermal 


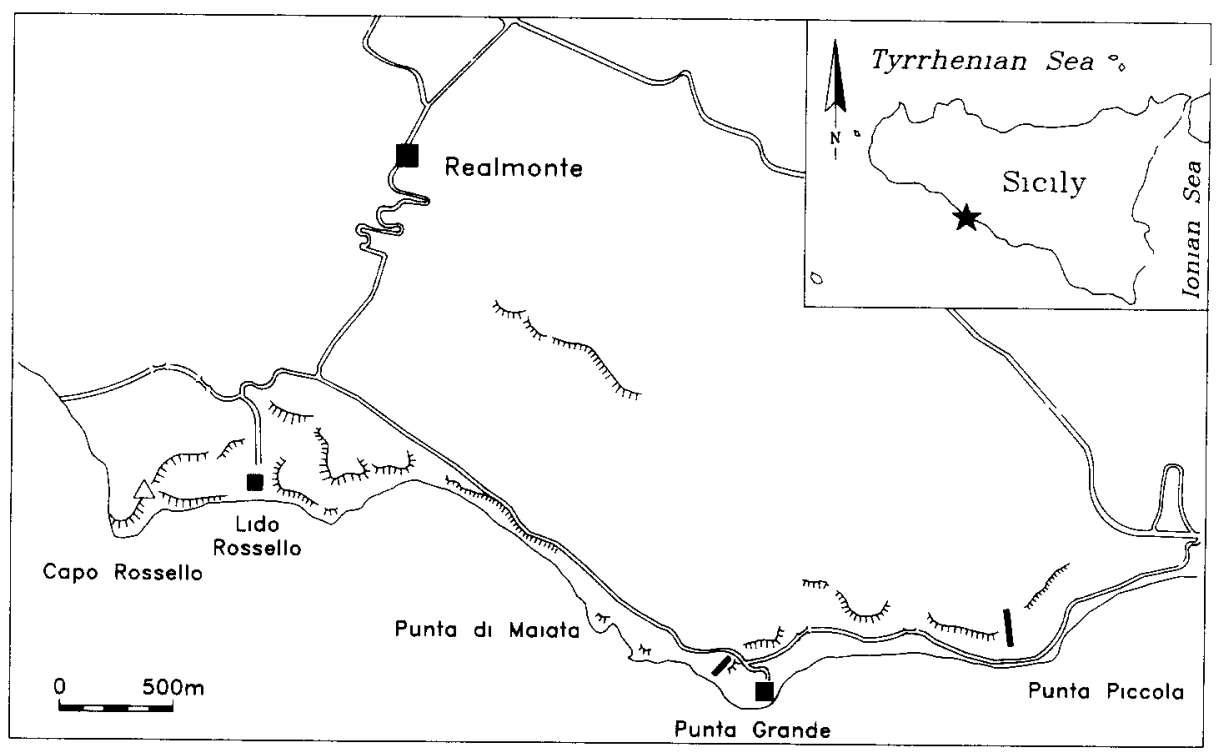

Fig 1 Location map of the Punta Grande and Punta Piccola sections.

demagnetization with small temperature increments.

Despite their low initial intensities, specimens from the Punta Grande section produce good results with clearly reversed polarity directions (Fig. 3a,b), even though in the upper part of the section some scatter is observed (Fig. 3b). The specimens from the Punta Piccola section show almost invariably results of very good quality (Fig. 3c,d). Soft secondary components are generally small or absent. The ChRM components show very uniform directions regardless of their polarity. The demagnetization diagrams show that the maximum unblocking temperature is close to $580^{\circ} \mathrm{C}$, which indicates that the characteristic component most probably resides in magnetite. The presence of magnetite suggests that the ChRM is of a primary origin.

The demagnetization diagrams furthermore show that normal and reversed directions are anti-parallel. Inclinations of the ChRM $\left(40^{\circ}\right)$ are consistently shallower than the inclinations of the geocentric axial dipole field for the locality $\left(57.5^{\circ}\right)$ or present day field $\left(52^{\circ}\right)$. This might point to an inclination error due to sedlment compaction and may be taken as another indication for the primary origin of the ChRM (Laj et al., 1982). ChRM directions obtained from progressive demagnetization are plotted in Fig. 4. Normal and reversed polarity levels are consistently grouped in distinct polarity zones. The Punta Grande section contains only reversed directions, whereas the Punta Piccola section yields three reversed and three normal polarity zones.

The next step is to correlate the composite Punta Grande and Punta Piccola polarity sequence to the magnetic polarity time scale based on sea floor anomalies (Berggren et al., 1985). In an earlier magnetobiostratigraphic study on the Early Pliocene of southern Italy, Zijderveld et al. (1986) have shown that the Globorotalia margaritae-Globorotalia puncticulata Zone ( = MPL3 of Cita, 1975 and Interval 3 of Spaak, 1983 ) extends up into the upper reversed Gilbert Chron. The three normal polarity zones in the composite Punta Grande and Punta Piccola section, therefore, are younger than the normal Cochita subchron and can only be correlated with the major part of the Gauss Chron (Fig. 5).

Calculated correlation coefficients between the stratigraphic thickness of the 4 Sicilian po- 


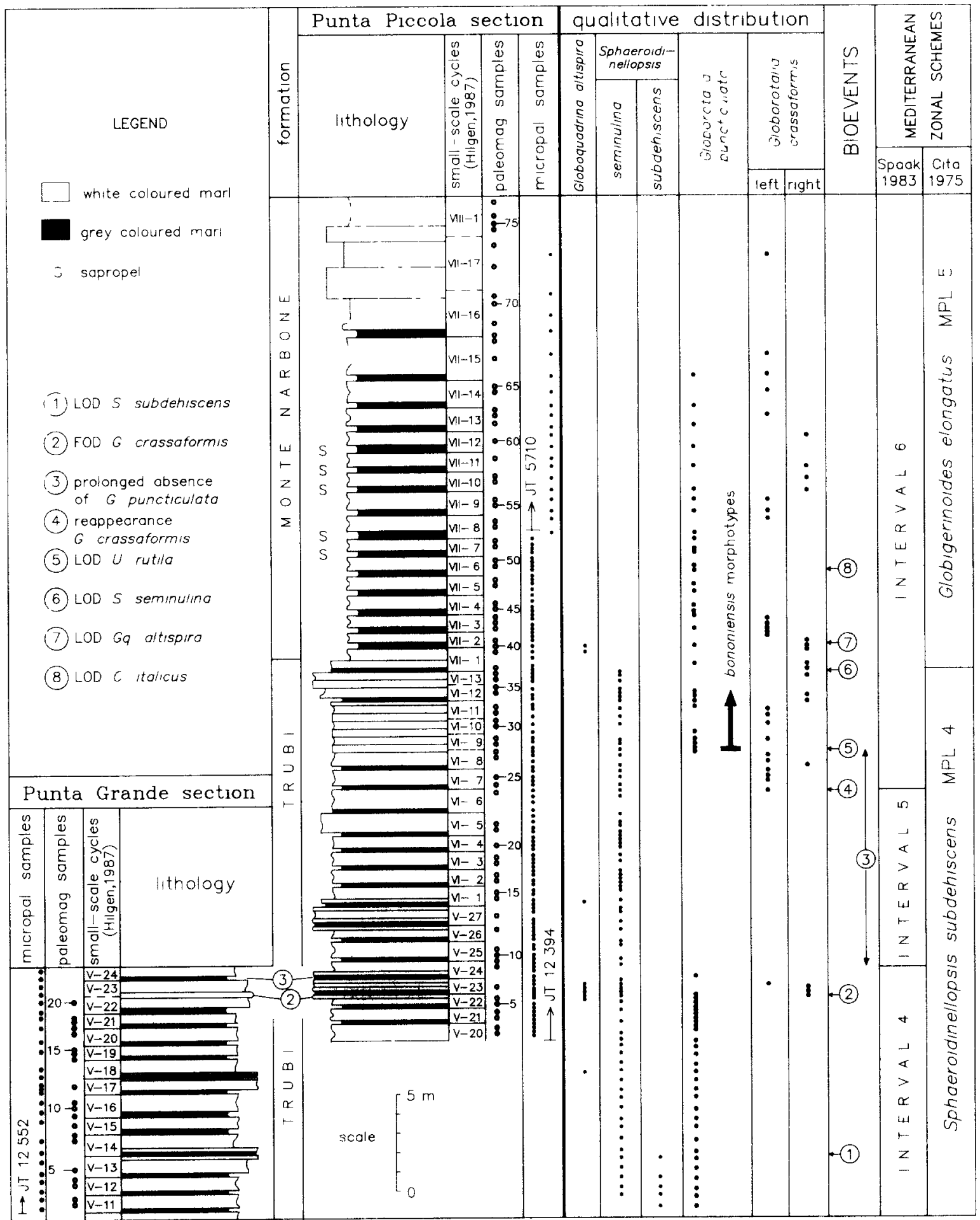

Fig 2 Lithology, sample position, distribution of selected planktonic foraminifers, bioevents and biostratıgraphy of the composite Punta Grande and Punta Prccola section 


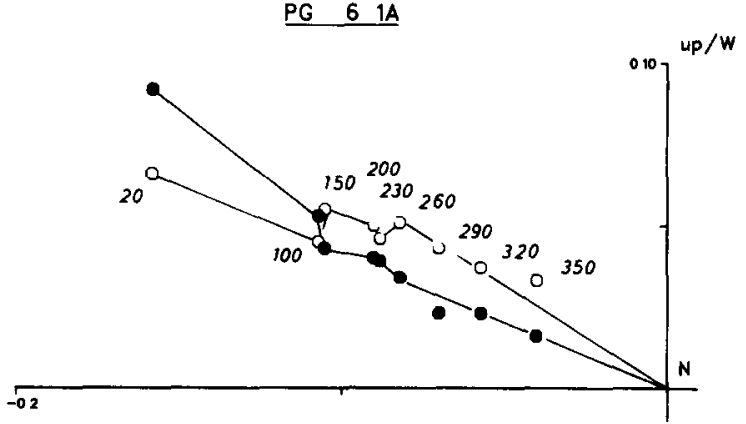

2

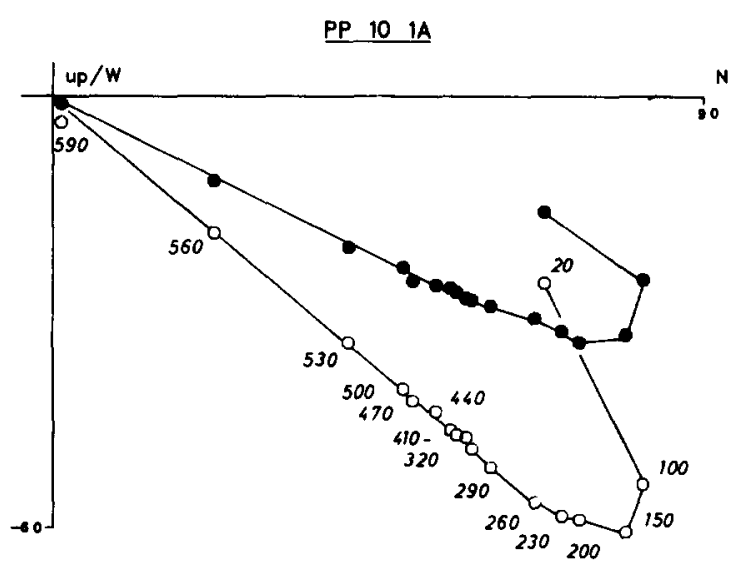

C

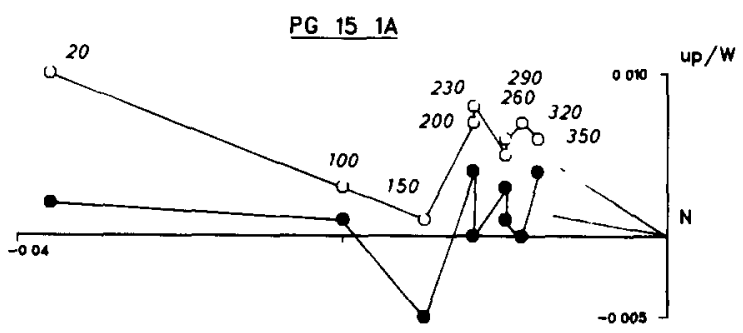

b

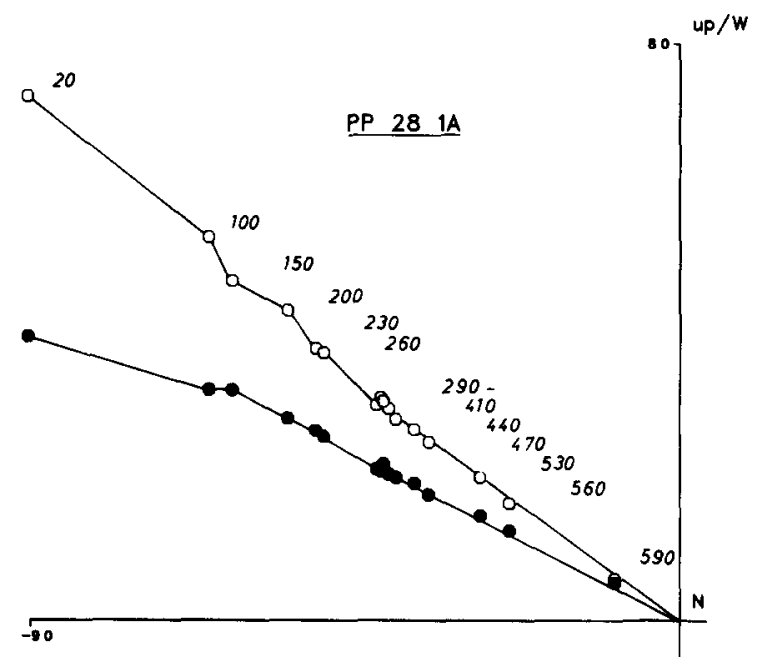

d

Fig 3 Representative thermal demagnetization vector diagrams of some selected samples in the Punta Grande section (a, b) and the Punta Piccola section (c, d). Solid (open) circles denote projection on the horizontal (vertical) plane; numbers indicate temperatures in ${ }^{\circ} \mathrm{C}$.

larity zones and the time-lengths of every possible sequence of 4 polarity zones from the magnetic polarity time scale (a method introduced by Langereis et al., 1984) also indicate that the composite Punta Grande and Punta Piccola section is equivalent to the major part of the Gauss Chron.

\section{Ages of early Late Pliocene bioevents}

Small-scale sedimentary cycles (Figs. 2, 5) between the base of the Gauss Chron and the top of the Kaena subchron have an average periodicity of $19.2 \mathrm{kyr}$ which is close to the figure of $20.5 \mathrm{kyr}$ for similar cycles in the Lower Pliocene of Calabria (Zijderveld et al., 1986) and of $19.1 \mathrm{kyr}$ in the Lower Pliocene of Sicily (Hilgen and Langereis, 1988) and suggests that also these early Late Pliocene small-scale cycles are related to the equinoxal precession.

The upper reversed part of the Gilbert Chron contains 12 such cycles, which on the basis of a $19.2 \mathrm{kyr}$ periodicity, provides an age of $3.63 \mathrm{Ma}$ for the base of the section. The upper normal 

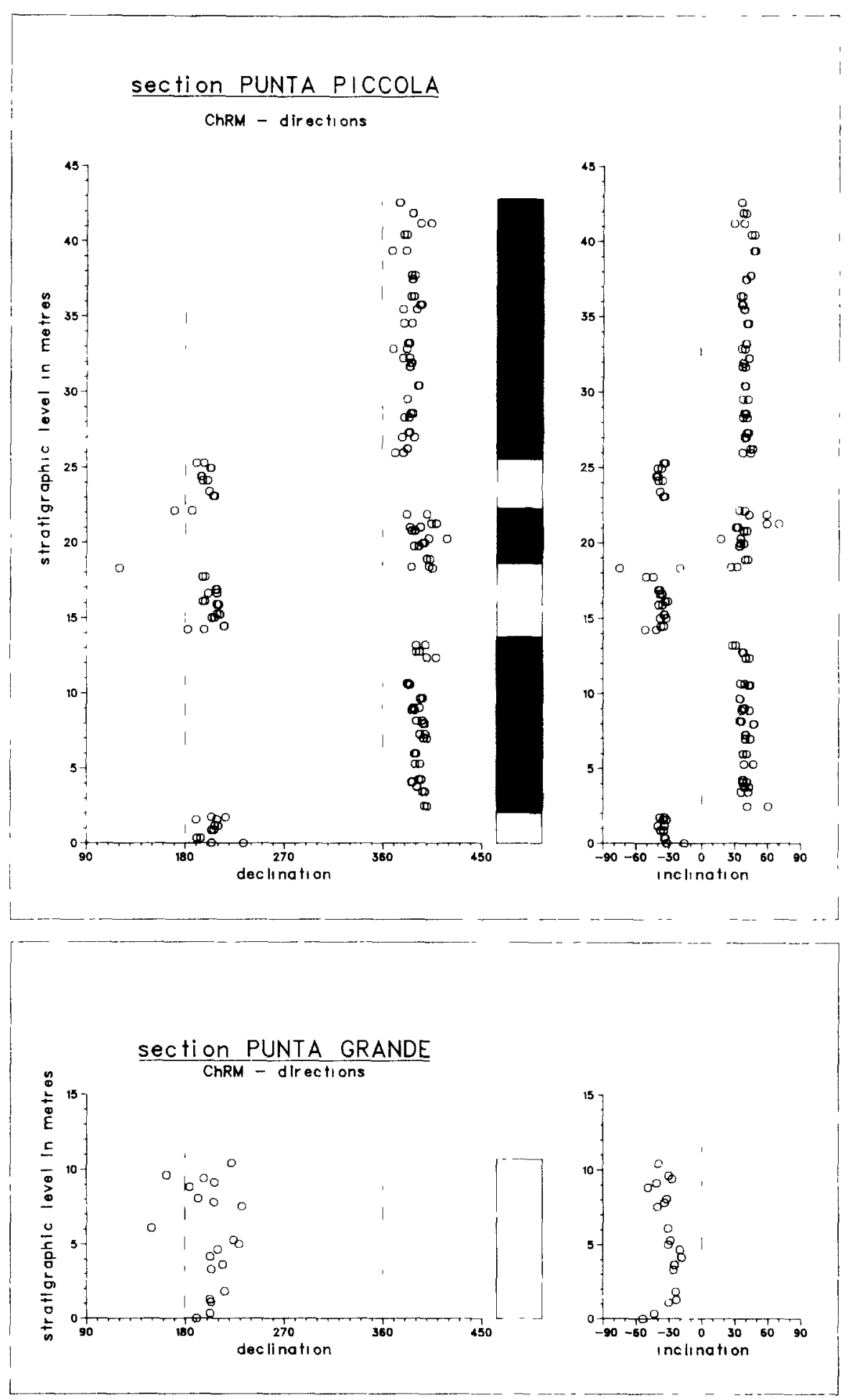

Fig 4 Dechnation and inclination of ChRM in the Punta Grande and Punta Piccola section. Black (white) intervals represent normal (reversed) polaritıes Dashed lines undicate declination of the geocentric axıal dipole field for the present latitude of the locality or zero inclination 


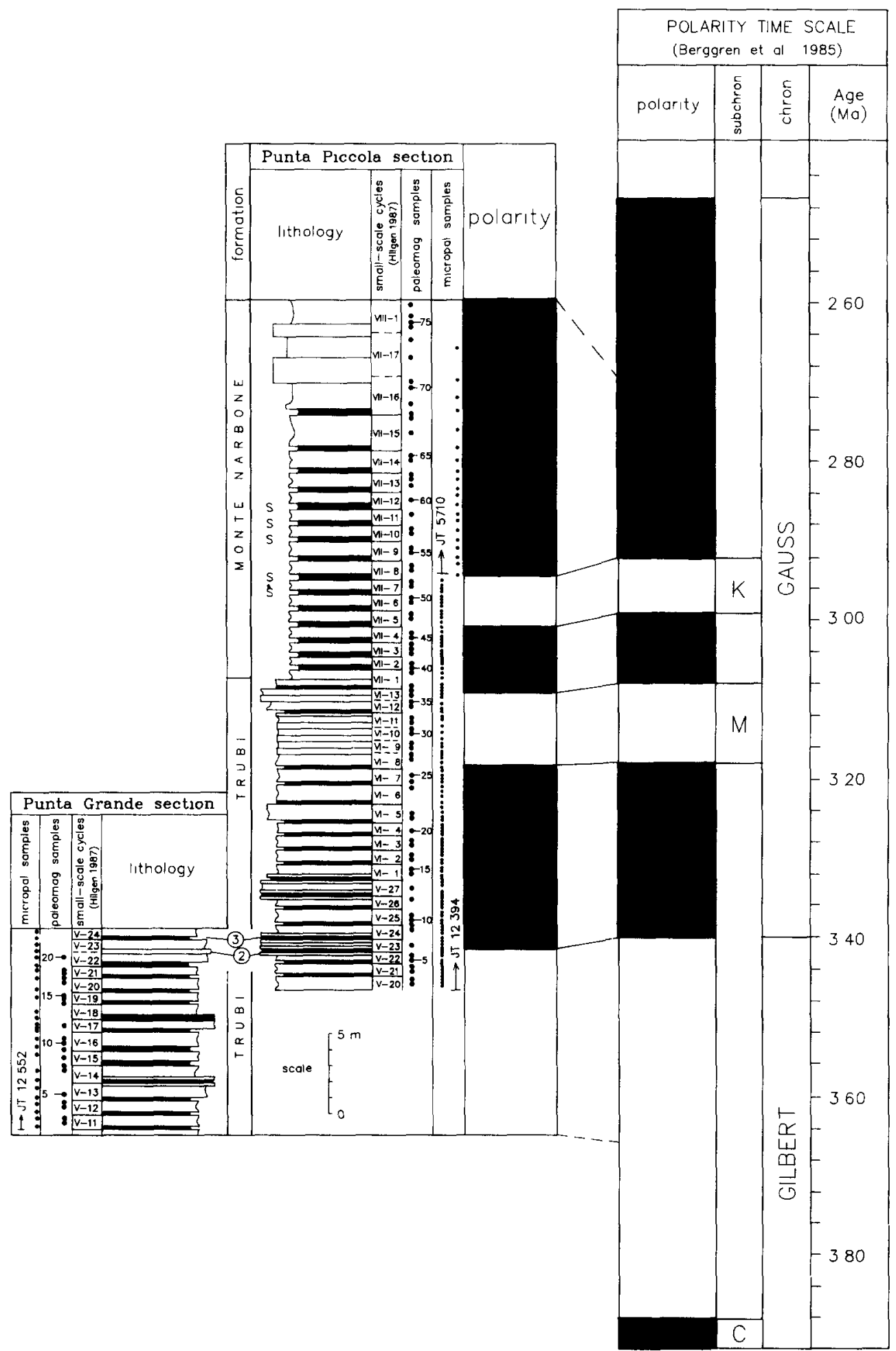

Fig. 5. Polarity sequence of the composite Punta Grande and Punta Piccola section and calibration to the magnetıc polarity time scale 
part of the Gauss Chron contains 11 cycles thus providing an age of $2.70 \mathrm{Ma}$ for the top of the section. In the uppermost 5 cycles, sedimentation rates increase progressively upward from 54 to $12.5 \mathrm{~cm} / \mathrm{kyr}$. Ages of bioevents between the base of the Gauss Chron and the top of the Kaena subchron are based on linear interpolation between paleomagnetic datum levels using the polarity time scale of Berggren et al. (1985). Ages of bioevents in the upper reversed part of the Gilbert and upper normal part of the Gauss Chron are based on the number of cycles between bioevents and their nearest paleomagnetic datum level. The complete age-calibrated sequence of Mediterranean bioevents between 363 and 2.70 Ma is shown in Fig. 6.

The LOD of Sphaeroidinellopsis seminulina in the Mediterranean has earlier been correlated to the Kaena subchron (Cita and Ryan, 1973), but appears by now to be firmly anchored in the middle normal subchron of the Gauss Chron at an age of 3.07 Ma (Fig. 6). This age fits remarkably well within the reported age range of 3.08 to $2.98 \mathrm{Ma}$ for this datum level in magnetobiostratigraphic records from the open ocean (Hays et al., 1969; Saito et al., 1975; Mazzel et al., 1979; Keigwin, 1982b; Weaver and Clement, 1987). Such a globally narrow timerange for the LOD of Sphaeroidinellopsis seminulina makes this datum level an ideal biochronohorizon in the early Late Pliocene of tropical-subtropical oceans. In contrast to the incıpıently corticated Sphaeroidınellopsis seminulina, fully corticate representatives of Sphaeroudınellopsis, viz. S subdehiscens, disappear much earlier, at $3.58 \mathrm{Ma}$, from the Mediterranean record (Fig. 6).

The LOD of Globoquadrina altıspira appears to correlate with a level within the middle normal subchron of the Gauss Chron at an age of $3.04 \mathrm{Ma}$ (Fig. 6). Also this age estimate compares well with the age-range of 3.10 to $2.85 \mathrm{Ma}$ for the LOD of Globoquadrina altıspira in the open ocean (Hays et al., 1969; Saito et al., 1975; Mazzei et al., 1979; Orr and Jenkins, 1980; Keigwın, 1982b; Weaver and Clement, 1987).
Although this datum level is potentially a useful biochronohorizon in the tropical-subtrop!cal ocean, its employment in cool-subtropical regions requires high-resolution sample series because in these regions Globoquadrina altispira is sparse and its record discontinuous. In the early Late Pliocene of the Mediterranean (for example) Globoquadrina altispıra is present only during 4 periods of less than 20,000 years each.

In contrast to the global time-significance of the LOD of Sphaeroidinellopsis seminulina and Globoquadrina altıspira other early Late Pliocene foraminiferal events in the Mediterranean seem to be time-bound on a more regional scale. Intra-Mediterranean time-stratıgraphic value probably holds for the LOD of Uvigerina rutrla at $3.16 \mathrm{Ma}$ and for the LOD of Cibicides italicus at $2.96 \mathrm{Ma}$. Earlıer age estımates of 3.00 and 2.40 Ma for both events (Sprovieri, 1986), based on sediment accumulation curves of Mediterranean sections by employing age-calibrated extra-Mediterranean bioevents, are too young. It is remarkable that the LOD of Ciblcides italıcus coincides with an earliest divers1fication in deep water miliolids (Fig. 6).

Also an age of $3.40 \mathrm{Ma}$ for the FOD of Globorotalia crassaformus is only significant for the Mediterranean region. In the central North Atlantic this species first occurs in the Nunivak subchron at 4.16 Ma together with Globorotalia puncticulata (Weaver and Clement, 1987). In the Mediterranean, Globorotalia punctıculata also arrives in the Nunivak subchron at $4.13 \mathrm{Ma}$ (Zijderveld et al., 1986), but without Globorotalia crassaformus, which enters the Mediterranean not before $3.40 \mathrm{Ma}$. Off northwestern Africa, at DSDP site 397, Globorotalia punctıculata and Globorotalia crassaformis again arrive s1multaneously (Spaak, 1983), although we think that an age-range of 4.16 to $4.13 \mathrm{Ma}$ for this event is a better estimate than the poorly constrained age of 4.32 $\mathrm{Ma}$ (Mazzei et al., 1979) All these data indicate that the spreading of Globorotalia crassaformis in the Mediterranean lags behind its spreading in the adjacent Atlan- 


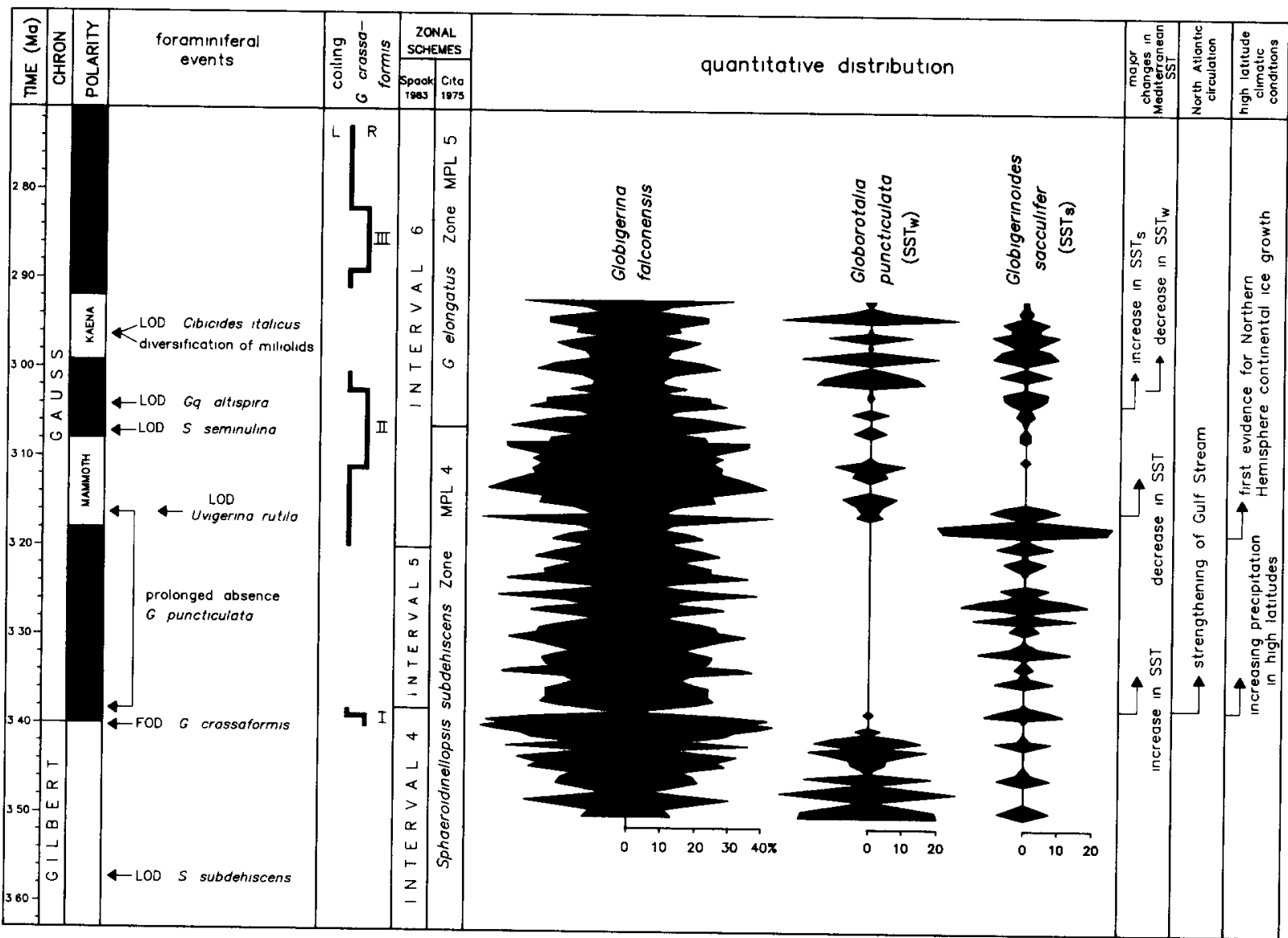

Fig 6. Age-calibrated abundances of Globigerinoides saccultfer, Globorotalia puncticulata and Globigerina falconensis and bioevents for the early Late Pliocene of Sicly. Globıgerınoides sacculifer reflects summer (SSTs) and Globorotalia puncticulata winter surface water temperatures (SSTw) Major changes in Mediterranean surface water temperatures are summarized and linked to major events in circulation and climate in the North Atlantic.

tic by at least 730,000 years. The early Late Pliocene record of Globorotalia crassaformus in the Mediterranean shows three intervals of dominantly right-coiled populations and two longerterm intervals in which this species is virtually absent (Fig. 6). This age-calibrated pattern provides a useful addition to the early Late Pliocene biochronology of the Mediterranean.

The early Late Pliocene record of Globorotalia puncticulata shows that this species is absent in the Mediterranean from 3.38 to $3.16 \mathrm{Ma}$ (Fig. 6) which is remarkably consistent with the record of the central North Atlantic DSDP site 609 (Raymo et al., 1987). At 3.16 Ma Med- iterranean populations of Globorotalia puncticulata start to slightly diverge morphologically from their Atlantic equivalents and on that basis Mediterranean populations are generally singled out as a separate species, viz. Globorotalia bononiensis. In reality, however, Globorotalla bononiensis is only an ecophenotype of Globorotalia puncticulata whose LOD in the Mediterranean has an estimated age of $2.31 \mathrm{Ma}$ (Hilgen, 1987) and, therefore, is time-equivalent with the LOD of Globorotalia puncticulata in the central North Atlantic (Weaver and Clement, 1987). Since we wish to avoid selfmade age discrepancies between the records of 
Globorotalia puncticulata in the Mediterranean and in the open ocean, Globorotalıa bononiensis is included in Globorotalıa punctıculata.

\section{Surface water temperature index}

A quantitative analysis on the early Late Pliocene planktonic foraminiferal fauna of Siclly includes the counting of 16 categories at 111 levels between 350 and $2.92 \mathrm{Ma}$. In this paper we focus on the abundance distribution of only three species, viz. Globorotalia puncticulata, Globigerinoides sacculifer and Globigerina falconensis.

Amongst these three species Globorotalia puncticulata is extinct. Its living relative Globorotalıa inflata is often classified as a transitional species (e.g. Tolderlund and Bé, 1971) but such a qualification is rather meaningless as long as habitat characteristics are not specified. According to Van Leeuwen (1988) Globorotalıa inflata flourishes in thermally homogeneous and cool surface waters with intermediate food levels. These habitat characteristics agree perfectly with high winter abundances of this species in the mid-latitude northwest Atlantic (Tolderlund and Bé, 1971; Hemleben and Spindler, 1983). Winter blooming of Globorotalia inflata in this region coincides with cooling and stirring of the surface water which erodes the summer thermocline, deepens the mixed layer and supplies the photic layer with nutrients. Also along the Iberian coast and in the western Mediterranean Globorotalia inflata attains highest abundances during winter (cf. winter plankton haul data of Glacon et al., 1974 and Duprat, 1983, with summer data of Bé and Hamlin, 1967 and Cifelli, 1974 ), when the upper layer is almost homothermal down to $200 \mathrm{~m}$ (McGill, 1961) and surface water temperatures fall below $16^{\circ} \mathrm{C}$ ( Duprat, 1983).

Summarizing, modern winter faunas in the mid-latitude North Atlantic and western Mediterranean are characterized by high abundances of Globorotalia inflata when the photic layer is cool, homothermal and relatively pro- ductive. We assume that the precursor of Globorotalia inflata, viz. Globorotalia punctıculata, had similar habitat characteristıcs.

Globigerinoldes sacculifer is an extant species which presently abounds in warm-subtropical to tropical waters (e.g. Bé and Hutson, 1977). This species is stenothermic with high minlmum surface water temperature requirements (e.g. Bé and Hutson, 1977). This is nicely illustrated by the virtual absence of Globigerinotdes saccullfer in the Gulf of Aqaba in glacial times when minimum surface water temperatures dropped below $18^{\circ} \mathrm{C}$ (Luz and Reiss, 1983). In the mid-latitude northwest Atlantic winter surface water temperatures are too low for this species and, therefore, Globlgerinordes saccullfer is an indicator of summer and early fall conditions in this region (Tolderlund and Bé, 1971). Although coastal upwelling (Wooster et al., 1976) dominates the summer fauna along the Iberian coast and the western extreme of the Mediterranean, Globlgerinoides sacculifer again is one of the summer species in the nonupwelling regions of the northeast Atlantic and western Mediterranean (cf summer plankton haul data of Bé and Hamlın, 1967 and Cifellı, 1974 with winter data of Glacon et al., 1974 and Duprat, 1983)

The contemporaneous blooming of Globigerınordes sacculifer and Globorotalia puncticulata at many levels in the early Late Pliocene of Sicily (Fig. 6) can only be understood if Globigerinotdes sacculffer represents the summer species and Globorotalia puncticulata the winter species. We, therefore, assert that the abundance fluctuations of both species in Fig. 6 reflect variations in summer and winter surface water temperature conditions in the early Late Pliocene of the Mediterranean.

Figure 6 also shows that both species are frequently absent over different periods of time. Since Globigerinoides sacculifer is the species which requires the highest surface water temperatures within this time-span at this location it seems reasonable to assume that whenever this species is absent, summer surface water 
temperatures were too low. Globorotalıa puncticulata on the other hand is the one which in the early Late Pliocene of Sicily requires the lowest surface water temperatures indicating that whenever this species is absent winter surface water temperatures were too high.

An $\mathrm{R}$-mode analysis on the percent data of 16 categories (employing computer program BALANC which corrects for closed sum effects, Drooger, 1982) shows that Globigerina falconensis is the only one amongst the abundant categories that correlates negatively $(P<0.01)$ with Globigerinoides sacculifer. This suggests that Globigerina falconensis is a sensitive recorder of summer surface water temperatures that are too low for Globugerinoides sacculffer. The slightly different surface water temperature requirements of Globigerina falconensis and Globigerinoides sacculifer agree with their distribution in the modern ocean where Globigerina falconensis flourishes in cool-subtropical waters (Malmgren and Kennett, 1977; Van Leeuwen, 1988) while Globigerinoudes sacculifer is abundant in tropical to warm-subtropical waters (e.g. Bé and Hutson, 1977).

\section{Variations in Mediterranean surface water temperature 2.92 to $3.50 \mathrm{Ma}$}

Abundance patterns of Globigerinoudes sacculifer, Globorotalia puncticulata and Globigerına falconensis are dominated by short-term fluctuations of about $20 \mathrm{kyr}$ (Fig. 6) and covary with precession-related variations in lithology. Peak-abundances of Globigerinoides sacculifer and Globorotalia puncticulata always correlate $(P<0.01)$ with the grey-coloured, carbonatepoor parts of the small-scale sedimentary cycles. This suggests that these layers correspond with higher summer and/or lower winter surface water temperatures than those of white layers. Consequently, seasonal contrasts might have been higher during the deposition of grey layers than during that of white layers.

The lower carbonate content in the grey-coloured parts of Early Pliocene cycles has been linked to non-carbonate dilution brought on by a periodical increase in precipitation and subsequent supply of river-born fine-grained sediments (De Visser et al., 1989). If a similar mechanism holds true for the early Late Pliocene grey-coloured, carbonate-poor intervals then these intervals represent periods of increased seasonality and precipitation. The linkage of the small-scale sedimentary cycles to the equinoxal precession and of the grey layers to a higher seasonality, implies that the summer solstice occurred near perihelion during the deposition of grey layers. Obviously, this phase of the precession cycle is accompanied by an increase in regional precipitation.

Sapropelitic interbeds in the higher part of the section are intercalated in the grey-coloured parts of the small-scale cycles (Fig. 2) indicating that the phase-relationship with the precession cycle is the same for both facies types. Early Late Pliocene sapropelitic layers, therefore, were most likely deposited at times when the summer solstice occurred near perihelion, i.e. in periods with enhanced seasonality and precipitation. A similar relationship between a near-perihelion summer solstice and increased precipitation has been proposed by Rossignol-Strick (1983) to explain the formation of Late Quaternary sapropels in the Eastern Mediterranean.

Since precession-related grey layers extend back into the earliest Pliocene (Hilgen, 1987) there must be some process additional to external forcing to initiate the formation of sapropelitic layers in Sicily $2.94 \mathrm{Ma}$. Such a process, which most likely is a tectonic one, would make the basin setting suitable for the formation of sapropels.

Short-term variations in early Late Pliocene Mediterranean surface water temperature, thus, are primarily controlled by the equinoxal precession. Additional control by the obliquity cycle is evidenced by $35 \mathrm{kyr}$ abundance fluctuations in Globigerinotdes sacculfer 3.50 to 3.35 Ma (Fig. 6).

The most conspicuous long-term faunal 
change is recorded by the abundance pattern of Globorotalia punctıculata. This species is permanently present, mostly in high percentages (Zacharıasse and Spaak, 1983), from its first occurrence level at $4.13 \mathrm{Ma}$ (Zijderveld et al., 1986 ) to $3.38 \mathrm{Ma}$ (Fig. 6). At $3.38 \mathrm{Ma}$ Globorotalia puncticulata vanishes and does not reappear until 3.16 Ma (Fig. 6). The vanıshing of Globorotalia puncticulata between 3.38 and 3.16 Ma would indicate that at $3.38 \mathrm{Ma}$ winter surface water temperatures began to rise above the maxımum temperature requirement of this species and that winter surface water conditions remained relatively warm for the next 220 kyr. The prolonged absence of Globorotalla puncticulata is coincident with a long-term increase in peak-abundances of Globigerinoldes sacculfer (Fig. 6). This long-term trend overlies the short-term, astronomically controlled, abundance variations of Globigerinoides sacculifer and reflects an overall upward increase in maxımum summer surface water temperatures that culminated at $3.18 \mathrm{Ma}$ when Globıgerlnotdes sacculffer reached highest percentage values of the entire Pliocene (cf. Zachariasse and Spaak, 1983). Sparse and scattered occurrences of Globorotalia menard $l$ and Neogloboquadrina dutertre $\iota$ between 3.38 and $318 \mathrm{Ma}$ also indicate that summer surface water temperatures in the Mediterranean were occasionally sufficiently high to provide shelter for (possibly expatriated) individuals of truly tropical species.

The time between 3.38 and 3.18 Ma thus represents a period of high average winter surface water temperatures and of increasing max1mum summer surface water temperatures. High surface water temperatures in the Mediterranean from 3.38 to $3.18 \mathrm{Ma}$ agree with a relative high abundance of discoasters and a scarcity of gephyrocapsids in this region (Driever, 1988) but conflict with a postulated cooling in the midlatitude North Atlantic at that time (Loubere and Moss, 1986; Raymo et al., 1987). Much of the evidence for a surface water cooling in the mid-latitude North Atlantic is based on the prolonged absence of Globorotalia puncticulata in DSDP Sites 548 (Loubere and Moss, 1986) and 609 (Raymo et al., 1987), which is assoc1ated with increased percentages of the cold-tolerant Neogloboquadrina atlantica. The latter species is a Late Miocene to Late Pliocene species indigenous to the mid to high-latitude North Atlantic (Poore and Berggren, 1975a) The habitat of Neogloboquadrina atlantica most likely is in cool water and the areal extent of this species, therefore, might be controlled by cool surface water conditions. However, abundances of Neogloboquadrina atlantıca within the area of distribution are not necessarily related to surface water temperatures, but - just as has been proposed for other neogloboquadrinids (Van Leeuwen, 1988) - they may be controlled by the total production in the photic layer. Therefore, we do not have to accept the postulated surface water cooling in the mid-latitude North Atlantic 3.4 to $3.2 \mathrm{Ma}$. Our data from the Mediterranean point to a warmıng between 3.38 and 3.18 Ma rather than to a cooling. Obviously, warm (winter) surface waters in the North Atlantic and Mediterranean expanded at $3.38 \mathrm{Ma}$ and reduced the distribution of Globorotalia puncticulata to an area north of Site 609 for the next $220 \mathrm{kyr}$. This interpretation agrees with the persistent occurrence of Globorotalia puncticulata in the Late Pliocene at Rockall Bank (Poore and Berggren, 1975b; Spaak, 1981).

From 3.18 to $3.15 \mathrm{Ma}$ abundances of Globlgerinoudes saccultfer drop to (near) zero values and remain that low unt1l 3.03 Ma (Fig. 6) Globorotalia puncticulata reappears at $3.16 \mathrm{Ma}$ and shows modest precession-related abundance variations until $3.02 \mathrm{Ma}$ (Fig. 6). Obviously, summer and winter surface waters in the Mediterranean rapidly cooled from 3.18 to $3.15 \mathrm{Ma}$ and remaned cool until about 3.03 Ma (Fig. 6).

Cooling of Mediterranean surface waters at $3.18 \mathrm{Ma}$ is consistent with an increase in gephyrocapsids and a concomitant decrease in discoasters in the Mediterranean (Driever, 1988 ), also with a change from warm to cool 
planktonic foraminiferal faunas (Ehrmann and Keigwin, 1987), and with an enrichment in $\delta^{18} \mathrm{O}$ (Keigwin, 1987) within the lower part of the Mammoth subchron in the North Atlantic DSDP Site 606. In the Caribbean, 3.2 Ma cooling conditions are marked by the arrival of Globorotalıa punctıculata (Keigwin, 1982b), while Prell (1984) recognized a brief increase in $\delta^{18} \mathrm{O}$ values in all three major oceans at about $3.2 \mathrm{Ma}$. Climatic cooling conditions at $3.18 \mathrm{Ma}$ thus seem to be ubiquitous. However, since first unequivocal evidence for ice-rafting in the North Atlantic does not occur before $2.55 \mathrm{Ma}$ (Ruddiman et al., 1987b) there is considerable uncertainty to what extent these cooling conditions are associated with Northern Hemisphere continental ice growth (Shackleton and Opdyke, 1977; Keigwin and Thunell, 1979; Keigwin, 1982a) or with cooling of high-latitude surface water and production of colder bottom water (Backman, 1979; Thunell and Williams, 1983; Prell, 1984).

Recently, Keigwin (1987) attributed the excess enrichment in $\delta^{18} \mathrm{O}$ values of benthic foraminifers over those of planktonic foraminiferal carbonate to a cooling of NADW in addition to a small glacial advance. Evidence for Northern Hemisphere continental ice growth at that time is furnished by a recalculated age of $3.18 \mathrm{Ma}$ (Mankinen and Dalrymple, 1979) for the oldest tills in Iceland (McDougall and Wensink, 1966) and suggests that climatic cooling at $3.18 \mathrm{Ma}$ most likely is related to the initiation of Northern Hemisphere ice growth.

The onset of Northern Hemisphere ice growth has long been associated with the emergence of the Panama Isthmus (e.g. Berggren and Hollister, 1977; Keigwin, 1978). The reason is that a closure of the Pacific connection would strengthen the Gulf Stream (Berggren and Hollister, 1977) causing warm surface waters to penetrate into higher latitudes and supply moisture necessary for initiating continental ice accumulation (Keigwin and Thunell, 1979).
Prolonged high winter surface water temperatures in the Mediterranean from 3.38 to 3.16 Ma coupled with a prolonged increase in maximum summer surface water temperatures culminating at $3.18 \mathrm{Ma}$ could indeed reflect a progressive strengthening of the Gulf Stream. A more vigorous Gulf Stream would inject larger volumes of warm surface water into the North Atlantic Drift and eastern boundary current, thus warming surface waters in the mid to highlatitude northeast Atlantic and Mediterranean. Strengthening of the Gulf Stream at $3.38 \mathrm{Ma}$ suggests that the closure of the Isthmus of Panama was not completed before that time and this agrees rather well with the severed faunal interchange between the Atlantic and Pacific oceans 3.3 to $3.0 \mathrm{Ma}$ (Keigwin, 1982b). The transport of larger volumes of warm surface water via the North Atlantic Drift into high latitudes might have subsequently stimulated high-latitude snow-fall, but whether snow-fall alone is sufficient to initiate Northern Hemisphere continental ice seems doubtful. As long as the snow cover melts off during summer, no net accumulation of snow will take place and thus no continental ice-sheet will form. Critical for a net accumulation of snow is a minimum summer insolation (Milankovitch, 1930; Weertman, 1976). Minimum summer insolation at Northern Hemisphere high-latitudes is attained during periods in which the summer solstice shows a maximum sun-earth distance with obliquity values at a minimum and we suggest that these conditions prevailed at $3.18 \mathrm{Ma}$. Once the net accumulation of snow changed to positive, continental ice could grow rapidly by the ice-albedo feedback.

The short-term enrichment in $\delta^{18} \mathrm{O}$ of planktonic and benthic foraminiferal carbonate in the mid-latitude North Atlantic indicates that the glacial advance at $3.18 \mathrm{Ma}$ is temporary (Keigwin, 1987) suggesting a waning of contınental ice shortly after initial growth.

Also in the Mediterranean summer and winter surface waters remained cool for a short period between 3.18 and $3.03 \mathrm{Ma}$ (Fig. 6). In- 
creased abundances of Globigerinoudes sacculifer at 3.03 Ma suggest that summer surface water conditions in the Mediterranean ameliorated at that time, whereas winter surface water temperatures kept falling as is evidenced by the increasing percentages of Globorotalia puncticulata (Fig. 6). Thus at about $3.03 \mathrm{Ma}$ seasonal contrasts steepened and this increase in seasonality might be attributable to an increase in orbital eccentricity. Increased eccentricity values and associated higher summer insolation at Northern Hemisphere high-latitudes at $3.03 \mathrm{Ma}$ could possibly explain why continental ice growth diminished shortly after its initiation at $3.18 \mathrm{Ma}$.

\section{Conclusions}

Paleomagnetic measurements on samples from 100 stratigraphic levels in the early Late Pliocene of Sicily provides an unprecedented hıgh-quality polarity sequence which extends from the upper reversed Gilbert to the upper normal Gauss subchron. The resultant chronology for the early Late Pliocene provides ages for the following principal Mediterranean bioevents:

1 FOD Globorotalia crassaform

$340 \mathrm{Ma}$
$338-316 \mathrm{Ma}$

2 prolonged absence of Globorotalia puncticulata

3 LOD Uvigerina rutila

LOD Sphaeroidinellopsis seminulina

LOD Globoquadrina altıspıra

LOD Cibicides italicus

$316 \mathrm{Ma}$

$3.07 \mathrm{Ma}$

$304 \mathrm{Ma}$

$296 \mathrm{Ma}$

Short-term variations in temperature of the surface water and in colour and carbonate content of the sediment are primarily controlled by the equinoxal precession. Higher summer and/ or lower winter surface water temperatures are always associated with grey-coloured, carbonate-poor layers suggesting that the seasonality is higher during the deposition of the grey-coloured layers than during that of the white-coloured facies. A higher seasonality during the grey-coloured facies suggests that at that time the summer solstice was near perihelion, whereas an inverse alignment occurred at the time of deposition of the white layers. This phase-relationship between the precession cycle and grey-coloured layers also applies for the sapropels which began to intercalate in the greycoloured facies at $2.94 \mathrm{Ma}$.

Long-term changes in surface water temperatures include a warming between 3.38 and 3.18 $\mathrm{Ma}$ followed by a cooling from 3.18 to $3.03 \mathrm{Ma}$. At 3.03 Ma summer and winter surface water temperatures started to diverge which suggests an increase in seasonality, possibly as a consequence of an increase in orbital eccentricity. The warming of Mediterranean surface waters at $3.38 \mathrm{Ma}$ is believed to be associated with the final elevation of the Isthmus of Panama. Consequent strengthening of the Gulf Stream injected larger volumes of warm surface water into the North Atlantic Drift and eastern boundary current. Thus surface waters warmed in the mid to high-latitude northeast Atlantic and Mediterranean. Surface water warming in the high latitude northeast Atlantic could have stimulated high-latitude snow-fall but to build-up continental ice requires a net accumulation of snow which can be achieved by lowering the summer insolation. We believe that minimum values of summer insolation at $3.18 \mathrm{Ma}$ triggered the net accumulation of snow. The increased ice-albedo feedback enabled a first and rapid expansion of Northern Hemisphere continental ice thus cooling surface waters in the northeast Atlantic and Mediterranean.

\section{Acknowledgements}

Thanks are due to P.J. Verplak for his assistance in the field and for measuring the paleomagnetic samples, to G.J. van het Veld for processing the micropaleontological samples and to $T$. van Hinte for draughtıng services. Discussion with J. Oerlemans (Institute of Meteorology and Oceanography, University of Utrecht) and W.J.M. van der Linden is highly appreciated. This study was financially sup- 
ported by Shell Internationale Petroleum Maatschappij B.V. (The Hague).

\section{References}

Backman, J , 1979 Plocene biostratıgraphy of DSDP sites 111 and 116 from the North Atlantic Ocean and the age of Northern Hemisphere glaciation Stockholm Contrib Geol , 32 115-137

Bé, A W H and Hamlin, W.H , 1967 Ecology of recent planktonic foramınifera, 3 Distribution in the North Atlantic during the summer of 1962. Micropaleontol, 13. 87-106

Bé, A W H and Hutson, W H , 1977 Ecology of planktonıc foraminifera and biogeographic patterns of life and fossil assemblages in the Indian Ocean Micropaleontol, $23 \quad 369-414$

Berggren, W A and Hollister, C D., 1977. Plate tectonıcs and paleocirculation. commotion in the ocean In $J$ Bonin and R S Dietz (Editors), The present state of plate tectonics Tectonophysics, 38 11-48

Berggren, W.A , Kent, D V , Flynn, J J and Van Couverıng, J A, 1985 Cenozoic geochronology Geol Soc Am Bull , 96 1407-1418

Cifellı, R, 1974 Planktonic foramınıfera from the Mediterranean and adjacent Atlantic waters (cruse 49 of the Atlantıc II, 1969) J. Foramınıferal Res , 4(4) 171-183

Cita, M B , 1975 Planktonic foramınıferal biozonation of the Mediterranean Pliocene deep sea record A revision Rıv Ital Paleontol Stratıgr, 8 527-544

Cita, M B and Ryan, W B F , 1973. Time scale and general synthesıs In Ryan, W B F , Hsu, K J et al, Intial Reports Deep Sea Drilling Project 13 U S Government Printıng Office, Washıngton, D C., 1405-1415

Drıever, B W M , 1988 Calcareous nannofossil bıostratıgraphy and paleoenvironmental interpretation of the Mediterranean Plıocene Utrecht Micropaleontol Bull, $36245 \mathrm{pp}$

Drooger, M M , 1982 Quantitative range chart analyses Utrecht Micropaleontol Bull , 26227 pp

Duprat, J , 1983 Les foramınıferes planctonıques du Quaternaire terminal d'un domaine pericontinental (Golfe de Gascogne, Côtes ouest-Ibériques, Mer d'Alboran) écologie-bıostratıgraphie Bull Inst Geol Bassın d'Aquitaine, Bordeaux, 33 71-150

Ehrmann, L M and Keigwin, L D , 1987 Middle Pliocene change in planktonic foraminiferal fauna at site 606 In Ruddıman, W F , Kıdd, R B , Thomas, E et al., Inıtıal Reports Deep Sea Drilling Project 94 U S Government Printıng Office, Washıngton, D C , 921-924

Glacon, G, Vergnaud-Grazzını, C and Sigal, M J , 1971 Premiers resultats d'un serie d'observations saisonnières des foraminifères du plancton Mediterranéen In A Farinacci (Editor), Proc Second Planktonic Conf, Roma, 1970, 555-581
Hays, J D , Saito, T , Opdyke, N.D. and Burckle, L.H , 1969 Plocene-Pleistocene sediments of the equatorial $\mathrm{Pa}$ cific Their paleomagnetic biostratıgraphy and climatic record Geol Soc Am Bull, 80 1481-1514

Hemleben, C and Spındler, M , 1983 Recent advances in research on living planktonic foraminifera. In J E Meulenkamp (Editor), Reconstruction of marine paleoenvironments Utrecht Micropaleontol Bull , 30 141170

Hilgen, F J , 1987 Sedımentary rhythms and high-resolution chronostratigraphic correlations in the Mediterranean Pliocene Newsl Stratigr , 17(2) 109-127

Hilgen, F.J and Langeress, C G , 1988 The age of the Miocene-Plocene boundary in the Capo Rossello area (Siclly) Earth Planet Sc1 Lett, 91 214-222

Keigwin, L D., 1978. Pliocene closing of the Isthmus of Panama, based on biostratigraphic evidence from nearby Pacifıc cores and Carıbbean Sea cores Geology, 6 630634

Keigwın, L D , 1982a. Stable isotope stratıgraphy and paleoceanography of sites 502 and 503 In Prell, W L, Gardner, J V et al , Initial Reports Deep Sea Drillıng Project, 68 US Government Printıng Office, Washington, D C., 445-453

Keıwin, L D , 1982b Neogene planktonic foraminifers from Deep Sea Driling Project sites 502 and 503 In Prell, W.L, Gardner, J V et al, Initial Reports Deep Sea Drilling Project, 68 U S Government Printing Office, Washington, D.C , 269-277

Kergwin, L D , 1987 Plıcene stable-ısotope record of Deep Sea Drilling Project site 606 sequential events of $\delta^{18} \mathrm{O}$ enrıchment begınnıng at $31 \mathrm{Ma}$ In Ruddıman, W F , Kıdd, R.B , Thomas, E. et al , Initıal Reports Deep Sea Drilling Project, 94 U S Government Printing Office, Washington, D C , 911-917

Keıgwn, L D. and Thunell, R C , 1979 Middle Plıocene climatic change in the western Mediterranean from faunal and oxygen isotopic trends Nature, 282 294-296

Laj, C , Jamet, M , Sorel, D. and Valente, J P , 1982 First paleomagnetic results from Mio-Plocene series of the Hellenic sedimentary Arc Tectonophysics, 86 45-67

Langereis, C G and Meulenkamp, J E , 1979 Comparison of two methods used to measure lithostratigraphical intervals in sections Potamidha 1 and 2 Utrecht Micropaleontol Bull , 21. 22-26

Langere s, C G , Zacharıasse, W J and Zuderveld, J D A , 1984 Late Miocene magnetobiostratıgraphy of Crete Mar Micropaleontol , 8 261-281

Leeuwen, van R J W., 1988 Sea-floor distribution and Late Quaternary faunal patterns of planktonic and benthic foraminifers in the Angola Basin Utrecht Micropaleontol Bull., 38 (in press)

Loubere, P and Moss, K, 1986 Late Plocene climatic change and the onset of Northern Hemisphere glaciation as recorded in the northeast Atlantic Ocean. Geol Soc Amer Bull , 77 818-828 
Luz, B and Reiss, Z , 1983 Stable carbon isotopes in Quaternary foraminufera from the Gulf of Aqaba (Elat), Red Sea In $J \mathbf{E}$ Meulenkamp (Editor), Reconstruction of marıne paleoenvironments. Utrecht Micropaleontol Bull , 30 129-140

Malmgren, B and Kennett, J P , 1977 Biometric analysis of phenotypic variation: Globigerina bulloıdes and Globigerina falconensis in the southern Indian Ocean J Foraminiferal Res , 7 130-148

Mankınen, E A and Dalrymple, C.B , 1979 Revised geomagnetic polarity time scale for the interval $0-5 \mathrm{~m}$ y $\mathrm{B} P$ J Geophys. Res , 84*615-626

Mazzeı, R , Raffi, I , Rı, D , Hamilton, N and Cita, M B., 1979 Calibration of Late Neogene calcareous plankton datum planes with the paleomagnetic record of site 397 and correlation with Moroccan and Mediterranean sections In Von Rad, U, Ryan, W.B F et al., Initial Reports Deep Sea Drilling Project, 47 Government Prınting Office, Washıngton, D C , 375-389

McDougall, I and Wensink, H , 1966. Paleomagnetism and geochronology of the Pliocene-Pleistocene lavas in Iceland Earth Planet Scr Lett, 1 232-236

McGill, D A , 1961 A preliminary study of the oxygen and phosphate distribution in the Mediterranean Sea Deep Sea Res , 8 259-269

Milankovitch, M, 1930 Mathematische Klimalehre und astronomische Theorie der Klimaschwankungen In W Koppen and R Geiger (Editors), Handbuch der Kl1matologie, IA, Borntraeger, Berlin, $176 \mathrm{pp}$

Orr, W N and Jenkins, G D , 1980. Eastern equatorial Pacific Pliocene-Pleistocene biostratigraphy Cushman Found. Spec Publ, 19 278-286

Poore, R Z and Berggren, W A, 1975a The morphology and classification of Neogloboquadrina atlantica (Berggren) J Foraminiferal Res., $5(2) \cdot 76-84$

Poore, R Z and Berggren, W A, 1975b Late Cenozoic planktonic foraminiferal biostratıgraphy and paleochmatology of Hatton-Rockall Basin. DSDP site $116 \mathrm{~J}$ Foraminiferal Res, 5 (4) 270-293

Prell, W L , 1984 Covanance patterns of foraminiferal $\delta^{18} \mathrm{O}$ An evaluation of Pliocene ice volume changes near 32 milhon years ago Science, 226 692-694

Raymo, M E , Ruddiman, W.F and Clement, B M , 1987 Plocene-Pleistocene paleoceanography of the North Atlantic of Deep Sea Drilling Project site 609 In: Ruddıman, W.F , Kıdd, R B., Thomas, E. et al , Initıal Report Deep Sea Drilling Project, 94 U S Government Printing Office, Washington, D C , 895-901

Rı, D , Sprovierı, R and Raffi, I, 1984. Calcareous plankton biostratigrapy and biochronology of the PlioceneLower Pleistocene succession of the Capo Rossello area, Sicily Mar Micropaleontol , 9. 135-180

Rossignol-Struck, M , 1983 African monsoons, an immediate climate response to orbital insolation Nature, 304 46-49

Ruddıman, W F , Backman, J, Baldauf, J, Hooper, P,
Kelgwn, L.D , Miller, K., Raymo, M. and Thomas, E, 1987a Leg 94 paleoenvironmental synthesis. In Ruddıman, W F , Kıdd, R B , Thomas, E. et al, Initıal Reports Deep Sea Drilling Project, 94 U S Government Printıng Office, Washıngton, D C , 1207-1215

Ruddıman, W F , McIntyre, A and Raymo, M , 1987b Paleoenvironmental results from North Atlantic sites 607 and 609 In Ruddıman, W F , Kidd, R B , Thomas, E et al, Initial Reports Deep Sea Drilling Project, 94 Government Printıng Office, Washington, D C , 855878

Saito, T., Burckle, L H and Hays, J.D., 1975 Late Mıcene to Pleistocene biostratıgraphy of equatorial Pacific sediments In T Saito and L Burckle (Editors), Late Neogene Epoch Boundaries, Micropaleontol Press, New York, 226-244

Shackleton, N J and Opdyke, N D , 1977 Oxygen ssotope and paleomagnetic evidence for early Northern Hemisphere glaciation Nature, 270 216-219

Spaak, P, 1981 The distribution of the Globorotalia inflata group in the Mediterranean Plocene. Proc K Ned Akad Wet, B, 84 201-215

Spaak, P , 1983 Accuracy in correlation and ecological aspects of the planktonic foraminiferal zonation of the Mediterranean Pliocene Utrecht Micropaleontol Bull . $28160 \mathrm{pp}$

Sprovier1, R., 1986. Paleotemperature changes and speciation among benthic foraminifera in the Mediterranean Phocene. Boll Soc Paleontol. Ital., 24 (1) 13-21

Suc, J P , 1984 Origin and evolution of the Mediterranean vegetation and climate in Europe. Nature, 307 429-432

Tauxe, L , Opdyke, N.D , Pasını, G and Elmı, C., 1983 Age of the Plio-Pleistocene boundary in the Vrica section, southern Italy Nature, 304 125-129

Thunell, R C and Wilhams, D F , 1983 The stepwise development of Pliocene-Pleistocene paleoclimatic and paleoceanographic conditions in the Mediterranean oxygen isotopic studies of DSDP sites 125 and 132 In J E Meulenkamp (Editor), Reconstruction of marme paleoenvironments Utrecht Micropaleontol Bull , 30 111-127

Tolderlund, D S and Bé, A W H, 1971 Seasonal distrıbution of planktonic foramınıfera in the western North Atlantic Micropaleontology, 23. 369-414

Visser, de J P , Ebbing, J H.J , Gudjonsson, L , Hilgen, F J , Jorissen, F J , Verhallen, P J J M. and Zevenboom, D , 1989 The origin of rhythmic bedding in the Pliocene Trubı of Sicily, Southern Italy Paleogeogr, Paleoclimat, Paleoecolog , 69(1/2) 45-66

Weaver, P P E. and Clement, B M., 1987 Magnetobiostratigraphy of planktonic foramıniferal datums Deep Sea Drilling Project Leg 94, North Atlantıc In. Ruddiman. W.F., Kıdd, R B , Thomas, E et al , Initial Reports Deep Sea Drilling Project, 94 U S Government Printing Office, Washington, D C , 815-829

Weertman, J, 1976 Milankovitch solar radiation varıa- 
tions and ice age ice sheet sizes. Nature, 261. 17-20.

Wooster, W.S., Bakun, A. and McLain, D R., 1976. The seasonal upwelling cycle along the eastern boundary of the North Atlantic. J Mar. Res , 34(2) 131-141.

Zachariasse, W J and Spaak, P , 1983. Middle Miocene to Pliocene paleoenvironmental reconstruction of the Mediterranean and adjacent Atlantic Ocean planktonıc foramıniferal record of southern Italy. In* J.E
Meulenkamp (Editor), Reconstruction of marıne paleoenvironments Utrecht Micropaleontol Bull , 30: 91110.

Zijderveld, J.D.A., 1975. Paleomagnetism of the Esterel rocks Thesis, University Utrecht (unpubl)

Zijderveld, J.D.A., Zachariasse, W.J. Verhallen, P.J.J.M and Hilgen, F J., 1986 The age of the Mrocene-Plocene boundary Newsl. Stratıgr , 16(3) 169-181 